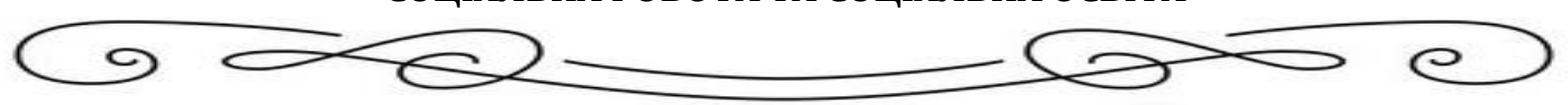

Europe: GlobalsciencecenterLP. Praha. Vol 1. № 4(4). P.78-82.

\title{
МОЛОДІЖНА РОБОТА
}

УДК 378.147.091.313-028.42

\section{ПРОЕКТНА ТЕХНОЛОГІЯ ЯК ЗАСІБ ПІДГОТОВКИ МАЙБУТНІХ ФАХІВЦІВ}

Балашова Світлана, кандидат педагогічних наук, доцент, доцент кафедри педагогіки, Київський національний університет імені Тараса Шевченка ORCID 0000-0003-4859-2837

e-mail: sbalashova@ukr.net

Головко Наталія, кандидат педагогічних наук, доцент, кафедра педагогіки, Київський національний університет імені Тараса Шевченка

ORCID 0000-0003-2400-7867

e-mail: Golovkonata@ukr.net

У статті подано результати дослідження особливостей використання методу проєктів у науково-досліднищькій діяльності студентів. Метод проєктів є технологією організації освітніх ситуацій, спрямованих на розв'язання проблем, технологія супроводу самостійної діяльності студентів із розв'язання проблеми і поєднує пошуковий метод навчання, групові методи, рефлексивні, презентативні, дослідницькі, пошукові та ін.

Автором з'ясовано, що метод проєктів спрямований на: вироблення самостійних досліднищьких умінь студентів; сприяння розвитку творчих здібностей $і$ логічного мислення; об'єднання знань, отриманих у ході навчального процесу, й пошук нової, додаткової, інформації професійного спрямування; залучення студентів до аналізу й вирішення певних життєвих ситуацій і проблем.

Ключові слова: метод проєктів; проєктна технологія; науково-дослідницька діяльність студентів; дослідницькі, творчі, рольові, інформаційні, ознайомчо-орієнтовні, практичноорієнтовані проєкти; етапи педагогічного проєктування.

\section{PROJECT TECHNOLOGY AS A MEANS OF TRAINING FUTURE SPECIALISTS}

Balashova Svitlana, Ph.D. (pedagogical), Associate Professor, Taras Shevchenko National University of Kyiv

ORCID 0000-0003-4859-2837

e-mail: sbalashova@ukr.net

Holovko Nataliya, Ph.D. (pedagogical), Associate Professor, Taras Shevchenko National University of Kyiv

ORCID 0000-0003-2400-7867

E-mail: Golovkonata@ukr.net

Вип. 2(5), 2020

ISSN 2618-0715 


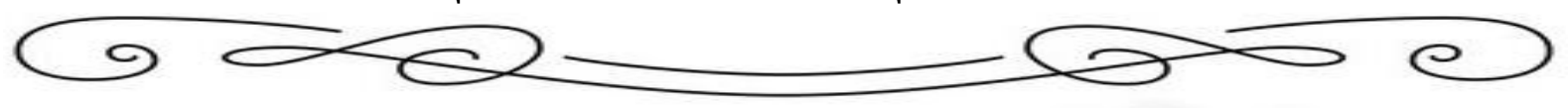

The pedagogical activity of the teacher in its essence is a scientific search, creative activity, has a pronounced research character. Today the project method is considered as one of the promising teaching methods because it creates conditions for creative self-realization of the participants of the educational process, increases motivation for acquiring knowledge, promotes the development of their intellectual abilities.

The project activity is aimed at developing students' creative abilities and abilities, their independence, striving for an ideal perspective transformation of the world through creative actions and operations in the process of creating a specific product - the project of the ideal and the real.

The method of projects is the technology of organization of educational situations aimed at solving problems, the technology of support of students' independent activity for solving problems, which involve presentation of results in the form of a specific product of activity. Given the benefits of the project method, we can assume that its use in the learning process will have a positive impact on the formation of professional culture in future professionals.

The work on the project has an innovative character, requires students to apply new knowledge, based on previously digested material; develops the ability to act and make decisions and resolve the conflicts; forms the desire and ability to learn independently.

Keywords: project method; design technology; research activities of students; research, creative, role-playing, informational, introductory-oriented, practice-oriented projects; stages of pedagogical design.

Постановка проблеми. Питання впровадження та застосування методу проєктів у педагогічній науці розглядалися у працях як вітчизняних, так і зарубіжних вчених, які досить неоднозначні у своєму тлумаченні щодо питань виникнення методу, його засновників та періодів розвитку.

Аналіз останніх досліджень і публікацій. Розробку методу проєктів здійснювали Дж. Дьюї, $\quad$ В. Кілпатрик, Д. Снезден, А. Папандреу, В. Монда, Д.Каттерік. Дослідження методу проєктів як засобу реалізації особистісно орієнтованого навчання спостерігається у наукових доробках Т. Башинської, Л. Ботько, Т. Волковської, С. Сисоєвої, З. Таран, О. Коперника та ін.

Проєктна технологія виникла ще в 20-ті роки XX століття в Сполучених Штатах Америки як метод проєктів, теоретичні й методичні основи якого закладені філософом і педагогом Дж. Дьюї та його учнем В. Кілпатриком. Вони стверджували, що умовами успішного навчання $\epsilon$ проблематизація навчального матеріалу, пізнавальна активність здобувача освіти, зв'язок навчання з досвідом, організація навчання у формі ігрової чи трудової діяльності.

У сучасній педагогічній науці існує велика кількість визначень поняття «метод проєктів». Так, наприклад, С. Гончаренко наголошував на тому, що метод проєктів «це організація навчання, за якою учні набувають знань і навичок у процесі планування і виконання практичних завдань - проєктів» [1, С. 203]. Вчений вважав, що метод проєктів базується на теоретичних концепціях прагматичної педагогіки. Метод проєктів може забезпечити розвиток творчої ініціативи й самостійності учнів і сприятиме зміцненню безпосереднього зв'язку між набуттям знань і вмінь та застосуванням їх у розв'язанні практичних завдань.

С. Сисоєва зазначає, що метод проєктів виступає як засіб реалізації особистісно-орієнтованої взаємодії, спрямований на особистісне спілкування; на розуміння педагогом внутрішнього світу студентів; створює умови для розвитку 


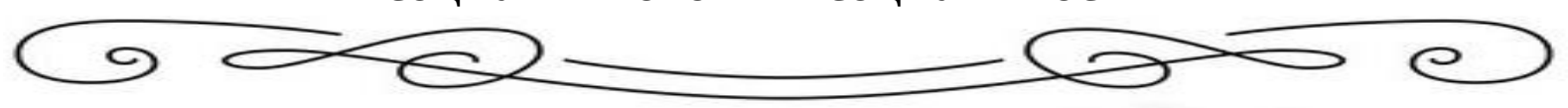

мотивації у творчий навчальної діяльності; стимулює прагнення зрозуміти установки і погляди один одного [2].

Мета статті полягає в теоретичному дослідженні особливостей використання методу проєктів у науково-дослідницькій діяльності студентів.

Виклад основного матеріалу дослідження. Метод проєктів $\epsilon$ технологією організації освітніх ситуацій, спрямованих на розв'язання проблем, технологія супроводу самостійної діяльності студентів із розв'язання проблеми і поєднує пошуковий метод навчання, групові методи, рефлексивні, презентативні, дослідницькі, пошукові та ін. Основною метою методу проєктів $\epsilon$ надання студентам можливості самостійного опанування знаннями в процесі вирішення практичних завдань чи питань, що потребують інтеграції знань із різних галузей, а дає можливість опанувати нові способи діяльності в соціокультурному середовищі.

Науковці зазначають, що проєкти сприяють творчим та дослідницьким здібностям у процесі реалізації особистісно-орієнтованого навчання. Відповідно до цього, спільна проєктно-творча діяльність визначається як спосіб реалізації особистісно-орієнтованої взаємодії, де студент реалізує свої можливості в спільно досягнутому продукті.

Перевагами даного методу є можливість одночасного формування багатьох базових професійних компетентностей. Метод проєктів - це особлива форма взаємодії викладача та студента, спрямована на вирішення конкретної наукової проблеми або ситуації, що передбачає створення матеріального чи духовного продукту з метою формування у студентів проєктної культури, професійних компетентностей, творчих навичок та умінь, умінь самостійно конструювати свої знання, орієнтуватися в інформаційному просторі, критично мислити. Враховуючи переваги методу проєктів, можемо припустити, що його використання у процесі навчання позитивно вплине на формування професійної компетентності майбутніх фахівців.

Методика впровадження методу проєктів або так званої проєктної технології передбачає створення відповідної проблемної ситуації під час вирішення якої студенти, оволодівши певною сукупністю академічних знань, здатні засобами проєктної діяльності показати як теоретичний бік розв'язання поставленої задачі, так і можливості практичного застосування отриманих результатів.

Мета використання методу проєктів полягає у формуванні навичок ефективного використання інформаційно-комунікаційних технологій при навчанні студентів різного віку за допомогою інноваційних педагогічних технологій, якими передбачається самостійна (індивідуальна чи групова) дослідницько-пошукова діяльність студентів.

Основу методу проєктів становить формування пізнавальних навичок у студентів, вміння незалежно конструювати свій багаж знань, орієнтуючись в інформаційному просторі, виховання власного критичного і творчого розумового процесу.

Метод проєктів завжди орієнтований на самостійну діяльність студентів, - 


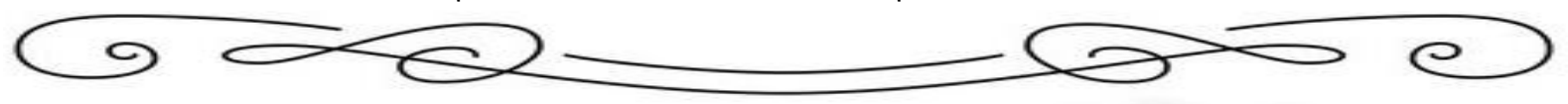

індивідуальну, парну або групову. Домінуючі методи виконання проєктів творчий, дослідницький, рольово-ігровий, інформаційний, практикоорієнтований, перспективно орієнтований. Тривалість виконання роботи короткострокова або довгострокова. Характер координації дій у процесі виконання проєкту - безпосередня (жорстка, гнучка) або прихована (неявна, що імітує учасника проєкту) координація. У процесі підготовки проєктної роботи задіяні різні види діяльності - розумова, комунікативна, практична i презентаційна.

О. Тадеуш поділяє метод проєктів на такі види: дослідницькі, творчі, рольові, інформаційні, ознайомчо-орієнтовні, практично-орієнтовані.

Дослідницькі проєкти - домінуючою діяльністю є дослідницька, мають структуру, наближену до наукового дослідження, передбачають актуальність і формулювання проблеми дослідження, його предмета і об'єкта, розробку плану, шляхів вирішення, чітко визначені цілі, вибір методології і висунення гіпотез, застосування відповідних методів дослідження і джерел інформації, обробку і систематизацію та обговорення, одержаних результатів (тези, стаття, доповіді на наукові конференції, есе, аналітичні роботи, вивчення та узагальнення перспективного педагогічного досвіду, виконання дипломних робіт).

Творчі проєкти не передбачають детально проробленої структури спільної діяльності, а лише домовленість про результати, які плануються та форму представлення. Це може бути твір, фільм, газета, відеофільм, свято, гра, експедиція та інші. Оформлення результатів творчого проєкту вимагає оформлення у вигляді сценарію відеофільму, плану твору, статті, репортажу, програми свята, дизайну, рубрик газети, альбому [3].

Рольові проєкти - це проєкти, у яких структура як і у творчих, залишається відкритою до завершення роботи. Характер і зміст проєкту визначається відповідно до ролей учасників (літературні персонажі, вигадані герої). Ступінь творчості в цих проєктах дуже висока і переважає рольова гра. Результати цих проєктів намічаються на початку виконання або вимальовуються лише в кінці.

Інформаційні проєкти спрямовані на збір, узагальнення та аналіз інформації про явище або об’єкт. Структура проєкту включає: актуальність, мету, джерела інформації; обробку інформації (аналіз, узагальнення, зіставлення, висновки); результат (стаття, реферат, доповідь, відео тощо); презентацію (публікація, обговорення в телеконференції і т.д.).

Ознайомчо-орієнтовні проєкти - вид інформаційних проєктів, що інтегруються в дослідницькі проєкти і $\epsilon$ їх органічною частиною (модулем). Проводяться з метою інформаційного пошуку та аналізу. Структура подібна до предметно-дослідницького проєкту, визначається: предмет інформаційного пошуку, поетапність пошуку з позначенням проміжних результатів; проводиться аналіз зібраних фактів, формулюються загальні висновки; пошук інформації 3 визначених напрямків, аналізованих фактів, узагальнення, висновки; загальний висновок, оформлення результатів (обговорення, презентація, зовнішня оцінка).

Практично-орієнтовані проєкти передбачають, що результат діяльності їх учасників визначається на самому початку і зорієнтований на соціальні інтереси 


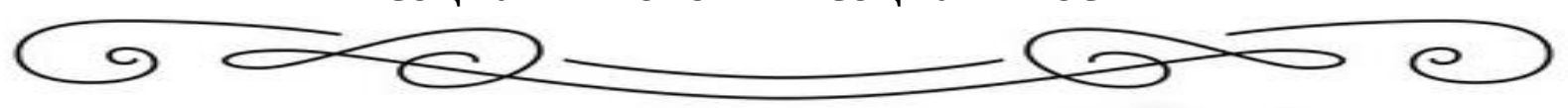

учасників. проєкт передбачає чітко визначену структуру, сценарій діяльності учасників з визначенням їх функцій, участь кожного учасника в оформленні кінцевого продукту. У даному проєкті важлива організація координаційної роботи та її поетапне обговорення; корекція зусиль як спільних, так й індивідуальних; організація одержаних результатів і впровадження їх в практику [3].

проєктивна технологія грунтується на таких принципах: принцип активності у виборі завдань проєкту та його опрацюванні; принцип життєвого, практичного характеру проєкту, його суспільно-корисну установку; принцип інтересу учнів до роботи; принцип поєднання теорії з практикою, знань та умінь; принцип здатності проєкту народжувати у процесі роботи нові проєкти; принцип здатності втілення проєкту; принцип самостійності; принцип творчості; принцип колективної діяльності.

Основними вимогами до застосування методу проєкту в освітньому процесі $\epsilon:$ визначення проблемного завдання (ситуації), вирішення якого потребує критичного та всебічного аналізу у процесі його дослідження; теоретична, практична, пізнавальна значущість проєкту; організація дослідницької роботи студентів (індивідуальна, парна, групова); формування змістової частини проєкту із фіксацією поетапних результатів; вибір методів дослідження; збір, систематизація, аналіз інформації; обговорення результатів роботи (презентація, публікація, веб-сторінка, тощо); оформлення та презентація результатів; оцінювання проєкту; висновки, визначення перспективних напрямів подальшого дослідження.

До етапів педагогічного проєктування відносяться: організаційноорієнтовний, технологічно-реалізаційний, результативно-узагальнюючий, презентативно-творчий.

Організаційно-орієнтовний етап. Функції викладача полягають у підвищенні мотивації учасників, формуванні мікрогрупи, наданні допомоги у визначенні мети і завдань проєкту, розробці плану реалізації ідеї, визначенні критеріїв оцінки діяльності на всіх етапах. Завдання студента полягають: у визначенні мети і завдань проєкту, розробці плану роботи, пошуку необхідної для початку роботи інформації.

Технологічно-реалізаційний етап. Викладач консультує по змісту проєкту, допомагає в систематизації, узагальненні матеріалів, знайомить 3 правилами оформлення проєкту, стимулює розумову активність студентів, відстежує практичні дії виконавців і оцінює проміжні результати кожного учасника, проводить моніторинг спільної діяльності. Студент збирає, аналізує й систематизує інформацію, обговорює іï в мікрогрупах, висуває і перевіряє гіпотези, виконує практичну частину проєкту, оформляє макет або модель проєкту, проводить самоконтроль.

Результативно-узагальнюючий. Викладач консультує з питань підготовки звіту про виконану роботу, процедури захисту проєкту, виступає в ролі експерта, аналізує виконану роботу, оцінює внесок кожного з учасників. Студент, у свою чергу, оформляє пакет документів, інформаційний стенд за результатами проєкту, готує презентацію результатів роботи. 


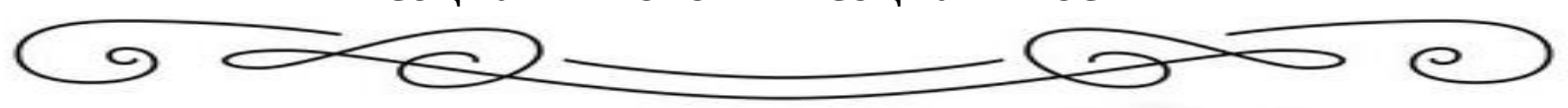

Презентативно-творчий. Викладач оцінює результати роботи. Студент, готуючи презентацію, повинен доповісти з таких основних питань: вступ (тема, мета, завдання навчального проєкту), результати навчального проєкту, висновки. Презентація навчального проєкту може бути представлена у формі постера, на якому автори в оригінальній формі подають добірку матеріалів (мультимедійна презентація, міні-підручник).

3 метою диференціювання процесу навчання, поглиблення науководослідницьких знань студентів, розвитку творчості щодо сприйняття актуальних проблем і самостійного конструювання своїх знань, ми сформували перелік проєктних завдань для студентів освітньо-наукової програми «Педагогіка вищої школи». Метою індивідуальних навчально-дослідницьких завдань ( проєктів) було самостійне вивчення частини програмного матеріалу, систематизація, поглиблення, узагальнення, закріплення та практичне застосування знань студента, розвиток навичок самостійної роботи.

Організовували діяльність студентів в декілька етапів.

3 метою чіткості організації методу проєктування ми визначили конкретну тему дослідження, індивідуальні завдання для дослідження, визначили заплановані результатів.

Для ефективності дослідження студенти були ознайомлені із методичними рекомендаціями, де вказувалась рекомендовані наукові джерела для самоосвіти, вимоги до якості проєкту, форми і методи кількісної оцінки результатів, алгоритми проєктування тощо.

Свої дослідження із обраної теми студенти оформляли відповідно до вимог: актуальність, необхідність, значущість обраного напряму; мета і завдання проєкту; визначення етапів його реалізації; механізм реалізації; обов'язки та відповідальність учасників реалізації проєкту; очікувані результати; оцінка та самооцінка виконаної роботи.

Критерії оцінювання проєктів виступають як основа забезпечення якісної реалізації цілей проєкту, вони повинні бути заздалегідь повідомлені студентам і визначатись індивідуально за самостійно виконане завдання. Для максимально якісного результату, ми розробили чіткі критерії оцінювання результатів роботи над проєктом кожного учасника, а саме: глибина розуміння та усвідомлення цілей проєкту та етапів роботи над ним; повнота висвітлення; логічність викладу; нестандартні підходи до рішення; оформлення інформації; комунікативна культура; культура мови під час презентації. Виступ студента перед комісією 3 проведення захисту проєкту має бути ретельно підготовленим, стислим, містити такі компоненти: чітко поставлену проблему; обгрунтування її актуальності; визначення об’єкта, предмета, мети й завдань дослідження; окреслення методології та методики його проведення; відомості про структуру роботи; короткий виклад зроблених автором узагальнень, висновків, де наводяться теоретичне і практичне значення отриманих результатів та можливі перспективи подальших досліджень.

Ми оцінювали успішність освоєння знань та універсальних умінь за результатами проєктування, які виявляються під час публічного захисту проєктів. 


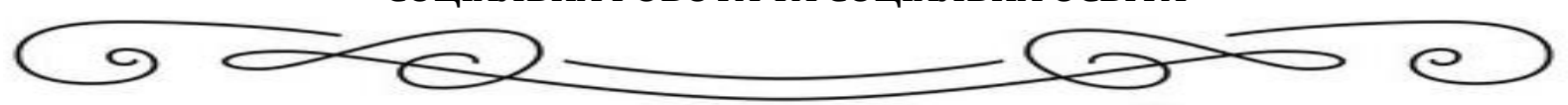

Захист проєктів відбувається у формі презентації (10-15 хв.), під час якої студенти представляють результати свої роботи, описують методи та прийоми, за допомогою яких було отримано інформацію, доповідають про проблеми, що виникли під час виконання проєкту, демонструють набуті знання, вміння, творчий потенціал. Найважливішим здобутком, який отримують студенти у процесі захисту проєктів $є$ формування навичок публічного виступу та презентації результату своєї роботи ( проєктного продукту), підтвердження власної компетентності.

У процесі оцінювання ми враховували низку важливих показників якості проєкту, а саме:

1.Чіткість формулювання мети i завдання проєкту, складність досліджуваних у роботі проблем, відповідність логічної побудови роботи поставленим цілям і завданням.

2. Якість і глибина теоретико-методологічного аналізу проблеми; широта й адекватність методологічного апарату; якість критичного огляду наукових джерел, наявність наукової полеміки, посилань на наукові джерела та визначення власної думки студента-автора проєкту.

3. Системність і глибина аналізу статистичних та фактичних матеріалів, наявність і переконливість узагальнень і висновків з аналізу, наявність і якість ілюстративних матеріалів у тексті роботи.

4. Наявність та логічний зв'язок заходів, що пропонуються для вирішення проблеми, що досліджується у роботі, з проведеному у роботі аналізом фактичних матеріалів, їх актуальність, реальність та наукова обгрунтованість, наявність альтернативних підходів до вирішення визначених проблем.

5. Науково-практична обгрунтованість розв'язання індивідуального творчого завдання, виявлені при цьому аналітичні та рефлексивні здібності.

6. Володіння культурою презентації, уміння стисло (в межах регламенту), послідовно й чітко викласти сутність і результати дослідження, здатність аргументовано захищати свої пропозиції, думки, погляди; повнота і грунтовність відповідей на запитання членів комісії, що приймає захист проєкту, на зауваження і пропозиції, що містяться у рецензії на проєктну роботу.

Ми погоджуємось із науковцями 3 тим, що викладач повинен дотримуватись наступних основних вимог щодо використання проєктнодослідної технології, застосування якої під час навчання $\epsilon$ показником високої кваліфікації педагога: наявність важливої в дослідницькому, творчому плані проблеми (завдання), що потребує інтегрованих знань, дослідницького пошуку для її розв'язання; практична, теоретична, пізнавальна вагомість передбачуваних результатів; самостійна (індивідуальна, парна, групова) діяльність студентів; структурування змістової частини проєкту (з указуванням поетапних результатів); використання дослідницьких методів; визначення проблеми досліджуваних завдань, що випливають з неї, висунення гіпотези їх розв'язання, обговорення методів дослідження, оформлення кінцевих результатів, аналіз отриманих даних, підбиття підсумків, коректування, висновки.

Висновки дослідження i перспективи подальших розвідок 


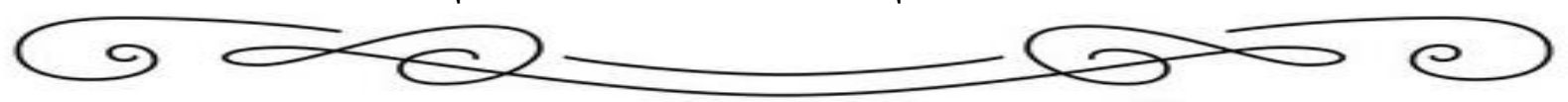

зазначеному напрямку. Таким чином, використання методу проєктів передбачає інтегровану дослідницьку, творчу діяльність студентів, спрямовану на отримання самостійних результатів за консультативної допомоги викладача. Викладач здійснює управління такою діяльністю і спонукає до пошукової діяльності студентів, допомагає у визначенні мети та завдань навчального проєкту, орієнтовних прийомів дослідницької діяльності та пошук інформації для розв'язання окремих навчально-пізнавальних задач. Метод проєктів активізує творчі можливості особистості студента: його інтелектуальну та емоційну сферу, індивідуальні особливості, впливає на розвиток таких рис характеру як цілеспрямованість, наполегливість, відповідальність, комунікабельність, адаптивність, креативність, усвідомлення моральних цінностей. Крім того, цей метод спрямований на розвиток навичок співробітництва та ділового спілкування в колективі, передбачає поєднання індивідуальної самостійної роботи 3 груповими заняттями, обговоренню дискусійних питань.

Підсумовуючи вищесказане, можна зазначити, що метод, який розглядається, спрямований на: вироблення самостійних дослідницьких умінь студентів; сприяння розвитку творчих здібностей і логічного мислення; об'єднання знань, отриманих у ході навчального процесу, й пошук нової, додаткової, інформації професійного спрямування; залучення студентів до аналізу й вирішення певних життєвих ситуацій і проблем.

\section{СПИСОК ВИКОРИСТАНИХ ДЖЕРЕЛ}

1. Гончаренко С. У. Український педагогічний словник / гол. ред. С. Головко. Київ: Либідь, 1997. $373 \mathrm{c.}$

2. Сисоєва С. Особистісно зорієнтовані технології: метод проектів: підручник для директора. Київ : Плеяди, 2005. №9-10. С. 25-28.

3. Тадеуш О. М. Метод проектів як форма продуктивного навчання студентів. Науковий часопис Національного педагогічного університету імені М. П.Драгоманова. Серія 16 : Творча особистість учителя : проблеми теорії і практики : зб. наук. праць. Київ : Вид-во НПУ імені М. П. Драгоманова, 2017. Вип. 29(39). С. 142-146.

\section{REFERENCES}

1. Honcharenko S. U. Ukrainskyi pedahohichnyi slovnyk / hol. red. S. Holovko. Kyiv: Lybid, 1997. 373 s.

2. Sysoieva S. Osobystisno zoriientovani tekhnolohii: metod proektiv: pidruchnyk dlia dyrektora. Kyiv : Pleiady, 2005. №9-10. S. 25-28.

3. Tadeush O. M. Metod proektiv yak forma produktyvnoho navchannia studentiv. Naukovyi chasopys Natsionalnoho pedahohichnoho universytetu imeni M. P. Drahomanova. Seriia 16 : Tvorcha osobystist uchytelia : problemy teorii i praktyky : zb. nauk. prats. Kyiv : Vyd-vo NPU imeni M. P. Drahomanova, 2017. Vyp. 29(39). S. 142-146. 